\title{
Seroprevalence of porcine reproductive and respiratory syndrome virus on swine farms in a tropical country of the Middle Americas: the case of Costa Rica
}

\author{
Ronald Meléndez $z^{1,2} \cdot$ Mónica Guzmán ${ }^{3} \cdot$ Carlos Jiménez ${ }^{4} \cdot$ Marta Piche $^{4} \cdot$ Emily Jiménez $^{5} \cdot$ Bernal León $^{3}$. \\ Juan M. Cordero ${ }^{3}$. Lisbeth Ramirez-Carvajal ${ }^{3}$ - Alberto Uribe ${ }^{6}$ - Arie Van Nes ${ }^{1}$ - Arjan Stegeman ${ }^{1} \cdot$ Hans Vernooij $^{1}$. \\ Juan José Romero-Zúñiga ${ }^{2}$
}

Received: 2 October 2020 / Accepted: 30 May 2021 / Published online: 18 August 2021

(c) The Author(s) 2021

\begin{abstract}
Porcine reproductive and respiratory syndrome virus (PRRSV) causes significant economic losses to the swine industry worldwide. Little is known regarding the epidemiology of this infection in tropical countries. To address this problem in Costa Rica, a seroepidemiological study was carried out in two phases. In the first phase, a pilot study was conducted in nine farms with the clinical diagnosis of PRRSV. In total, 265 pig serum samples were collected from animals ranging in age from 1 to 15 weeks of age. This study aimed to establish the duration of maternal immunity in piglets, to identify the period of viremia, and to determine when seroconversion occurs. In the second phase, a cross-sectional serology study was performed on a representative sample of the Costa Rican national herds in the second phase. The twenty-five selected farms represent all provinces and were classified according to herd size (100 to 2000 sows). In each farm, pigs aged 8, 10, and 12 weeks were sampled, as well as gilts based on the pilot study. In total 1281 pigs were sampled across all 25 farms. The aim of the cross-sectional study was to quantify the seroprevalence of PRRSV in Costa Rican pig farms and to describe its geographical distribution in this tropical country. The prevalence of positive farms was $44 \%$ (11/25), and these farms were located in six of the seven provinces of Costa Rica. Overall, 58\% (344/596) of the pigs were seropositive to PRRSV. The age of the pigs and the ecozone where farms were located were significantly related with PRRSV seroprevalence in animals and herds, respectively.
\end{abstract}

Keywords Epidemiology $\cdot$ Prevalence $\cdot$ PRRS $\cdot$ Reproduction $\cdot$ Serological diagnosis $\cdot$ Swine production $\cdot$ Virus

\begin{tabular}{|c|c|c|}
\hline $\begin{array}{l}\text { Ronald Meléndez } \\
\text { ronaldma03@gmail.com }\end{array}$ & & $\begin{array}{l}\text { Arie Van Nes } \\
\text { A.VanNes@uu.nl }\end{array}$ \\
\hline $\begin{array}{l}\text { Mónica Guzmán } \\
\text { monguzman@gmail.com }\end{array}$ & & $\begin{array}{l}\text { Arjan Stegeman } \\
\text { J.A.Stegeman@uu.nl }\end{array}$ \\
\hline $\begin{array}{l}\text { Carlos Jiménez } \\
\text { cajinsa@yahoo.com }\end{array}$ & & $\begin{array}{l}\text { Hans Vernooij } \\
\text { J.C.M.Vernooij@uu.nl }\end{array}$ \\
\hline $\begin{array}{l}\text { Marta Piche } \\
\text { mmpo@gmail.com }\end{array}$ & & $\begin{array}{l}\text { Juan José Romero-Zúñiga } \\
\text { juan.romero.zuniga@una.cr }\end{array}$ \\
\hline $\begin{array}{l}\text { Emily Jiménez } \\
\text { emilyjim.13@gmail.com }\end{array}$ & 1 & $\begin{array}{l}\text { Department of Farm Animal Health, University of Utrecht, } \\
\text { Utrecht, the Netherlands }\end{array}$ \\
\hline $\begin{array}{l}\text { Bernal León } \\
\text { bleon@ senasa.go.cr }\end{array}$ & 2 & $\begin{array}{l}\text { School of Veterinary Medicine (EMV), Universidad } \\
\text { Nacional, Heredia, Costa Rica }\end{array}$ \\
\hline $\begin{array}{l}\text { Juan M. Cordero } \\
\text { juan.cordero@senasa.go.cr }\end{array}$ & 3 & Ministry of Livestock and Agriculture, Heredia, Costa Rica \\
\hline $\begin{array}{l}\text { Lisbeth Ramirez-Carvajal } \\
\text { lizramirez@gmail.com }\end{array}$ & 4 & $\begin{array}{l}\text { Department of Virology, School of Veterinary Medicine, } \\
\text { Universidad Nacional, Heredia, Costa Rica }\end{array}$ \\
\hline $\begin{array}{l}\text { Alberto Uribe } \\
\text { jose.alberto.uribe@hotmail.com }\end{array}$ & $\begin{array}{l}5 \\
6\end{array}$ & $\begin{array}{l}\text { Faryvet Company, Heredia, Costa Rica } \\
\text { Boehringer Ingelheim, Guadalajara, Jalisco, México }\end{array}$ \\
\hline
\end{tabular}

Ronald Meléndez

ronaldma03@gmail.com

Mónica Guzmán

monguzman@gmail.com

Carlos Jiménez

Marta Piche

mmpo@gmail.com

Emily Jiménez

Bernal León

bleon@senasa.go.cr

Juan M. Cordero

Lisbeth Ramirez-Carvajal

Alberto Uribe

jose.alberto.uribe@hotmail.com

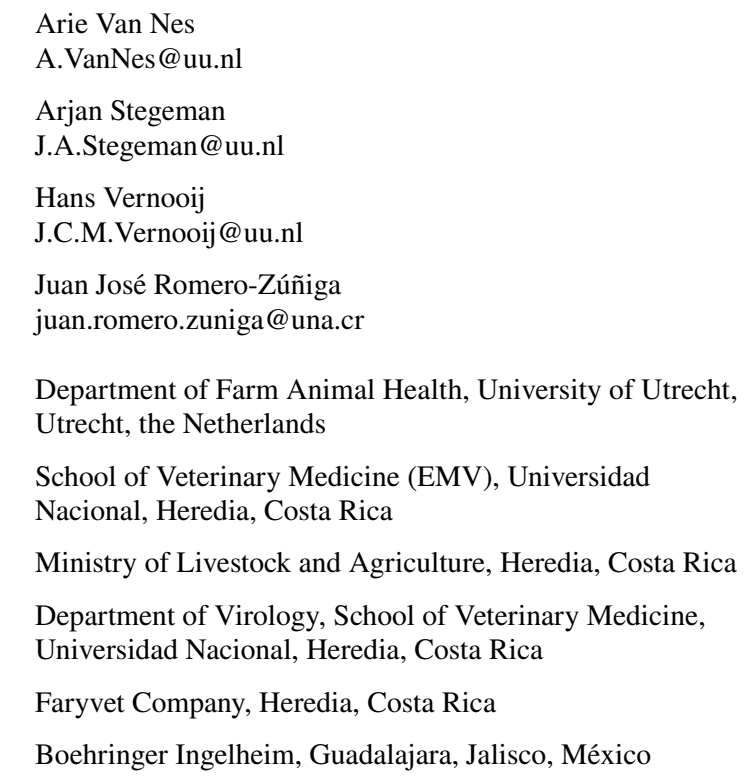

Boehringer Ingelheim, Guadalajara, Jalisco, México 


\section{Introduction}

Porcine reproductive and respiratory syndrome virus (PRRSV) is one of the most important pig pathogens worldwide from an economic perspective. Holtkamp et al. (2010) calculated the costs associated with this disease to be around 663 million USD/year in the USA. In Europe, average losses related to PRRSV outbreaks were estimated to be around two piglets per sow per year (Nieuwenhuis et al., 2012).

As climate may influence the virus spread within and between farms, it is difficult to infer the occurrence and distribution of PRRSV in a tropical country from observations in countries with a more moderate climate. In the past, some studies have been carried out to assess the PRRSV infection prevalence in Central America, México (Morilla et al., 2003), Colombia (Mogollón et al., 2006), Venezuela (Diaz, 2006), and the Dominican Republic,(Ventura et al., 2013), but there are no recent reports about the disease. This also holds for Costa Rica, a tropical country located in Central America between Nicaragua and Panama, where PRRSV was first detected in 1996 but which has received little attention since.

Holdridge (1987) has identified various climate zones (ecozones) in Costa Rica: moist-low mountain forest, moist-pre mountain forest, very moist-low mountain forest, very moist-pre mountain forest, very wet tropical forest, and rainy-low mountain forest. This research aimed to assess the seroprevalence of PRRSV in pig farms of Costa Rica and to estimate its association with the age of the pigs, farm size, geolocation, distance, time, and ecozones.

According to the Livestock National Census (INEC, 2014, 2015), there are 14,600 pig holders in Costa Rica, but most of them have backyard farms. There are only around 150 commercial pig farms, and these farms produce $80 \%$ of the country's pork. The total number of sows in Costa Rica is approximately 39,000, and the number of pigs slaughtered per year rounds 780,000 .

\section{Material and methods}

\section{Sample size}

In the first phase, a total of 260 pigs ( 1 to 15 weeks of age) from 9 highly PRRSV virus infection-suspected farms were sampled. All samples were tested in parallel with a commercial enzyme-linked immunoassay (IDEXX Laboratories: $100.0 \% \mathrm{Se}, 99.7 \% \mathrm{Sp}$ ) and endpoint PCR (Zorzetto- Fernandez, 2016).

The second phase, a serological analysis was performed using the IDEXX PRRS X3 kit (cat. 99-40,959). Only 87 out of all of the 150 pig commercial farrow-to-finish farms were affiliated to the National Chamber of Pig Farmers. These 87 farms were classified as large ( $>500$ sows, $\mathrm{n}=14$ ), medium-sized (200 to 500 sows, $\mathrm{n}=62$ ), or small $(<200$ sows, $n=11)$. Twenty-five of these farms were selected using stratified sampling. Vaccination against PRRSV has never been applied on these farms.

The sample size to determine presence of infection in each farm was based on 5\% within-herd prevalence (95\% confidence level), resulting in 50 to 60 samples, depending on herd size (Cannon et al., 1982). We sampled pigs of 8, 10, and 12 weeks of age, as well as gilts. A total of 450 blood samples were obtained from the eight large farms, 550 from 12 medium farms, and 278 from 5 small farms. The starting point for the distance and time determinations was the Juan Santamaria International Airport, located in the middle of the central zone of the country (Alajuela). Based on this, distances and journey length (time determinations) from each farm to the designated starting point were estimated and retrieved using Google Maps.

\section{Laboratory testing}

\section{Blood samples analysis}

The blood samples collected were placed in portable coolers that maintained refrigeration temperatures $\left(4{ }^{\circ} \mathrm{C}\right)$ and were transported to the laboratory within $8 \mathrm{~h}$. Once in the laboratory, the samples were centrifuged for $10 \mathrm{~min}$ at $14,000 \mathrm{rpm}$. The sera were separated and stored in $1.5 \mathrm{ml}$ vials (Eppendorf) at $-80^{\circ} \mathrm{C}$ until analysis.

\section{Determination of the serological status of the animals}

A commercial ELISA with reported $100.0 \%$ sensitivity and 99.7\% specificity was used following the manufacturer's instructions (IDEXX PRRS 3XR Ab ELISA; IDEXX Laboratories Inc. West brook, Maine, USA). This assay uses a specific epitope of the PRRSV nucleocapsid for testing the presence of antibodies against PRRSV-1 and PRRSV-2.

\section{Data capture and editing}

The geographical location of every farm included in this study was obtained from the "SIREA reconoce los esfuerzos ambientales de las instituciones" (2016) and depicted using ArcGIS ${ }^{\circledR}$ software ("ESRI 2011. ArcGIS Desktop: Release 10. Redlands, CA: Environmental Systems Research Institute" (2011)), firstly by province and also according to the Holdridge's life zone classification (Holdridge, 1987). Costa Rica has twelve major life zones (Alfaro Murillo et al., 2013) defined more precisely twelve major life zones in Costa Rica (Fig. 1). Note that Holdridge also uses altitude, precipitation, and rain, evapotranspiration, and luminosity. 
Fig. 1 Within-herd seroprevalence of 25 farms depicted in a Costa Rican's life ecozone map (Holdridge, 1971). The withinherd seroprevalence is depicted by spots: red $=$ high $(>30)$; yellow $=$ medium $(15-30)$; green $=(<15)$; black $=(0)$

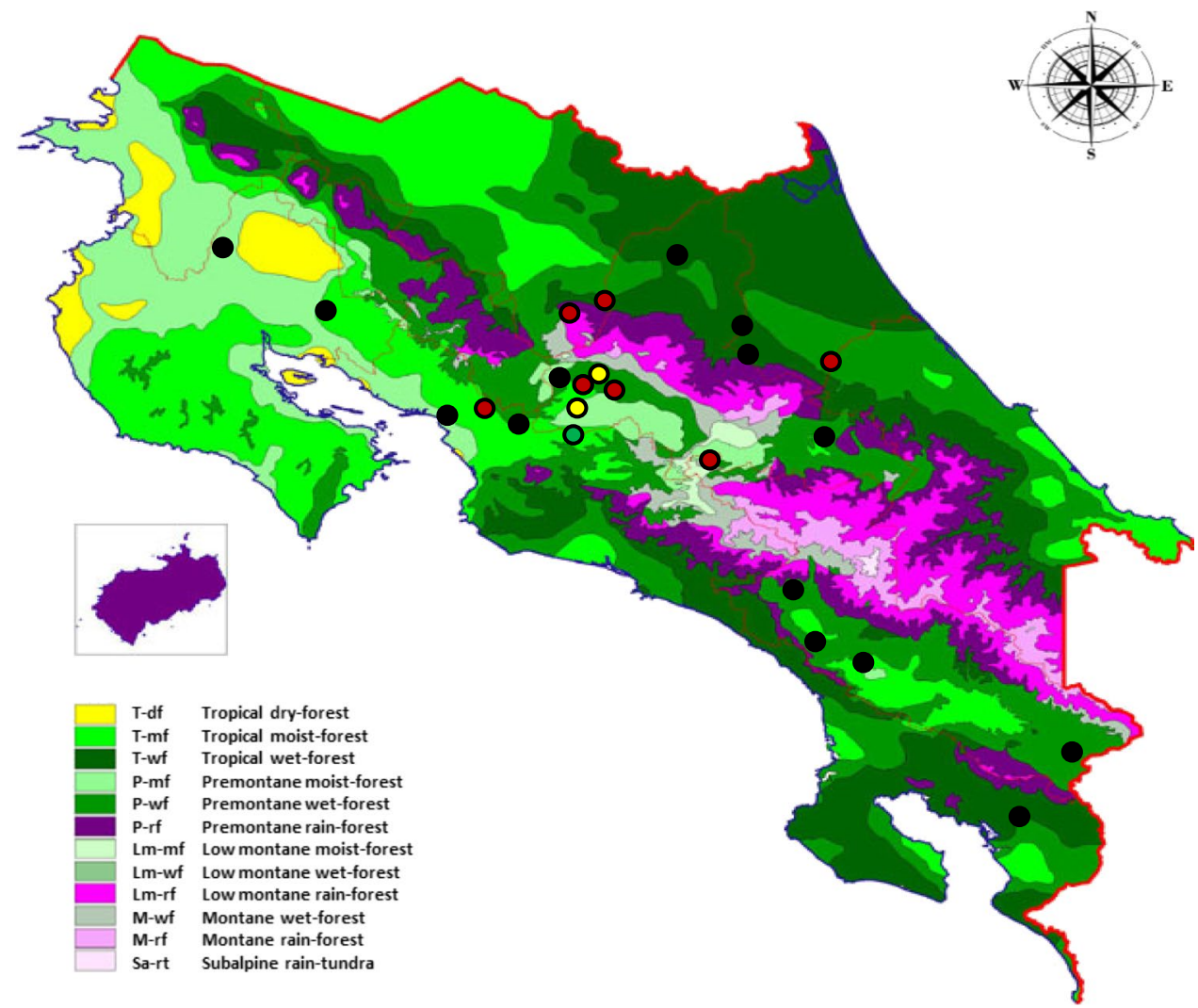

These life zones are defined and named according to the variation of temperature and precipitation in each area and the elevation above sea level. In Costa Rica, all forests are classified as tropical. Regarding humidity, they can be dry, moist, wet, and humid, whereas the elevational belt can be basal (0-700 masl); premontane (700-1400 masl); low montane (1400-2700 masl); montane (2400-3700 masl); subalpine (2400-3820 masl) (Table 1). In order to ease the description, the life zones were grouped and summarized from 12 ecozones into 6 ecozones: $1, \mathrm{P}-\mathrm{wf}=$ premontane wet forest; $2, \mathrm{~T}-\mathrm{mf}=$ tropical moist forest; $3, \mathrm{P}-\mathrm{mf}=$ very humid premontane forest; $4, \mathrm{~T}-\mathrm{wf}=$ tropical very humid forest 5 , P-rf $=$ montane rain forest $6, \mathrm{~T}-\mathrm{wf}=$ tropical wet forest. The decision to switch from 12 to 6 ecozones was based on the pattern of temperature and rainfall. We do not have farms in the study with extreme weather conditions, neither hot nor cold.

\section{Statistical analysis}

First, a univariable logistic regression model was run using seropositivity at farm level as an outcome variable and farm size, age of the pigs, province, ecozone, distance, and traveling time to the farms since a reference
Table 1 The altitude floor, temperatures, and altitude range of the most frequent life zones of Costa Rica according to Holdridge's life zone classification

\begin{tabular}{llll}
\hline Altitude floor & Life zone & Temp $\left({ }^{\circ} \mathrm{C}\right)$ & Altitude range (masl) \\
\hline $\begin{array}{l}\text { Basal } \\
\text { (Coast influence) }\end{array}$ & $\begin{array}{l}\text { Dry forest (T-df) } \\
\text { Rain forest (T-mf) } \\
\text { Very humid forest (T-wf) }\end{array}$ & $24-700$ \\
$\begin{array}{l}\text { Premontane } \\
\text { (Coast influence) }\end{array}$ & $\begin{array}{l}\text { Vet forest (P-mf) } \\
\text { Very humid forest (P-wf) }\end{array}$ & $24-18{ }^{\circ} \mathrm{C}$ & $700-1400$ \\
Bosque pluvial (P-rf) & & \\
Rain forest (Lm-mf) & $6-12{ }^{\circ} \mathrm{C}$ & $1400-2700$ \\
Very humid forest (Lm-wf) & & \\
Montane & $\begin{array}{l}\text { Rain forest (Lm-rf) } \\
\text { Very humid forest (M-wf) }\end{array}$ & $6-12{ }^{\circ} \mathrm{C}$ & $2400-3700$ \\
Rlpine diving & $\begin{array}{l}\text { Rain forest (M-rf) } \\
\text { Rain forest (Sa-) }\end{array}$ & $3-6{ }^{\circ} \mathrm{C}$ & $2400-3820$ \\
\hline
\end{tabular}


point in the center of the country. Secondly, taking only the seropositive farms into account, a mixed effect logistic regression model was run at individual pig level (596 pigs). A stepwise backward model selection procedure was used based on the Akaike's Information Criterion (AIC; smaller AIC is a better fitting model) to select the best fitting model. Statistical program SAS (SAS/STAT ® 9.3 User's Guide Introduction to Regression Procedures, n.d.) was used to run the analyses.

\section{Results}

The results obtained in the first phase about the dynamic of PRRSV indicate that maternal immunity is prolonged up to 3 weeks of life, that viremia occurs in the period between 10 and 15 weeks of life, and finally, that seroconversion occurs between weeks 10 and 15 . In the second stage, a total of $11 / 25(44.0 \%)$ farms were seropositive to PRRSV. The overall animal seroprevalence in this study was $26.9 \%$ (344/1281) 95\% CI (24.5-29.4). The median within-herd seroprevalence in the seropositive farms was $58 \%$ (344/596), ranging from 1 to 100 . In positive farms, seroprevalence increased with age; the seroprevalences were $39.4 \%$ in pigs of 8 weeks of age and $76.9 \%$ in breeders (Table 2). Geographically, all five farms located in the east-south region of the country tested negative. Farms located in the province of Guanacaste were all negative, while at least one of the sampled farms was positive in the other provinces. Moreover, the highest seroprevalence was observed in the life zones P-mf and P-wf (Table 3). Therefore, age and ecozones were significantly correlated with the seroprevalence in the statistical analysis (Table 3).

\section{Discussion}

The estimated prevalence of PRRSV in the national pig herd of Costa Rica was $44 \%$. The median within-herd seroprevalence in the seropositive farms was $58 \%$. The overall prevalence of PRRSV found in Canada was 37.1\% (Magar \& Larochelle, 2004) very similar in the USA (Bautista et al., 1993), México (Batista et al., 2004), and Spain (López-Soria et al., 2010).

Of all the variables studied in the mixed-effect logistic regression model, only the age and the ecozones (Table 3) had a significant correlation with the seroprevalence. In the first stage, it was determined that the viremia begins at week seven and can extend until 15 weeks of age, while the production of antibodies starts at week 10. The link between the drop in maternal antibodies and the onset of viremia occurred in piglets at 10 weeks of age. The
Table 2 Frequencies for positive results both at farm and animal level in swine farms of Costa Rica. Results are presents for all farms ( 25 farms, 1278 animals) and positive farms (11 farms, 596 animals)

\begin{tabular}{|c|c|c|c|c|c|c|c|}
\hline \multirow[t]{3}{*}{ Variable } & \multirow[t]{3}{*}{ Level } & \multicolumn{4}{|l|}{ All farms } & \multirow{2}{*}{\multicolumn{2}{|c|}{$\begin{array}{l}\text { Positive farms } \\
\left(+\mathrm{F}_{\mathrm{T}=} 11\right) \\
\begin{array}{l}\text { Animal }\left(+\mathrm{A}_{\mathrm{T}}=\right. \\
596)\end{array}\end{array}$}} \\
\hline & & \multicolumn{2}{|c|}{$\operatorname{Farm}\left(\mathrm{F}_{\mathrm{T}}=25\right)$} & \multicolumn{2}{|c|}{$\begin{array}{l}\text { Animal } \\
\left(\mathrm{A}_{\mathrm{T}}=1278\right)\end{array}$} & & \\
\hline & & $+\mathrm{f}_{\mathrm{t}} / \mathrm{F}_{\mathrm{T}}$ & $\%$ & $+\mathrm{a}_{\mathrm{t}} / \mathrm{A}_{\mathrm{T}}$ & $\%$ & $\mathrm{a}_{\mathrm{t}} / \mathrm{A}_{\mathrm{T}}$ & $\%$ \\
\hline \multirow[t]{3}{*}{ Farm size } & Small & $1 / 5$ & 20.0 & $43 / 79$ & 54.4 & $43 / 43$ & 100.0 \\
\hline & Medium & $7 / 12$ & 58.3 & $190 / 715$ & 26.6 & $190 / 350$ & 54.3 \\
\hline & Large & $3 / 8$ & 37.5 & $111 / 487$ & 22.8 & $111 / 203$ & 54.7 \\
\hline \multirow[t]{4}{*}{ Age } & $8 \mathrm{wks}$ & & & $54 / 310$ & 17.4 & $54 / 137$ & 9.4 \\
\hline & $10 \mathrm{wks}$ & & & $68 / 295$ & 23.1 & $68 / 139$ & 48.9 \\
\hline & 12 wks & & & $82 / 311$ & 26.4 & $82 / 138$ & 59.4 \\
\hline & Replacem & & & $140 / 365$ & 38.4 & $140 / 182$ & 76.9 \\
\hline \multirow[t]{7}{*}{ Province } & Alajuela & $5 / 7$ & 71.4 & $149 / 374$ & 39.8 & $149 / 284$ & 52.5 \\
\hline & Cartago & $1 / 2$ & 50.0 & $62 / 108$ & 57.4 & $62 / 72$ & 86.1 \\
\hline & Guanacaste & $0 / 2$ & 0.0 & $0 / 127$ & 0.0 & & \\
\hline & Heredia & $1 / 3$ & 33.3 & $43 / 90$ & 47.8 & $43 / 45$ & 95.6 \\
\hline & Limón & $1 / 3$ & 33.3 & $27 / 174$ & 15.5 & $27 / 57$ & 47.4 \\
\hline & Puntarenas & $1 / 4$ & 25.0 & $43 / 183$ & 23.5 & $43 / 43$ & 100.0 \\
\hline & San José & $2 / 4$ & 50.0 & $20 / 225$ & 8.9 & $20 / 95$ & 21.1 \\
\hline \multirow[t]{2}{*}{ Ecozone } & P-mf & $5 / 10$ & 50.0 & $157 / 515$ & 30.5 & $157 / 267$ & 58.8 \\
\hline & P-w & $6 / 15$ & 40.0 & $187 / 766$ & 24.4 & $187 / 329$ & 56.8 \\
\hline \multirow[t]{2}{*}{ Distance from capital $(\mathrm{km})$} & $\leq 50$ & $2 / 13$ & 15.4 & $273 / 666$ & 41.0 & $273 / 495$ & 55.2 \\
\hline & $>55$ & $9 / 12$ & 75.0 & $71 / 615$ & 11.5 & $71 / 101$ & 70.3 \\
\hline \multirow[t]{2}{*}{ Trav. time from capital (min.) } & $\leq 30$ & $2 / 14$ & 14.3 & $273 / 730$ & 37.4 & $273 / 495$ & 55.2 \\
\hline & $>50$ & $9 / 11$ & 81.8 & $71 / 551$ & 12.9 & $71 / 101$ & 70.3 \\
\hline
\end{tabular}




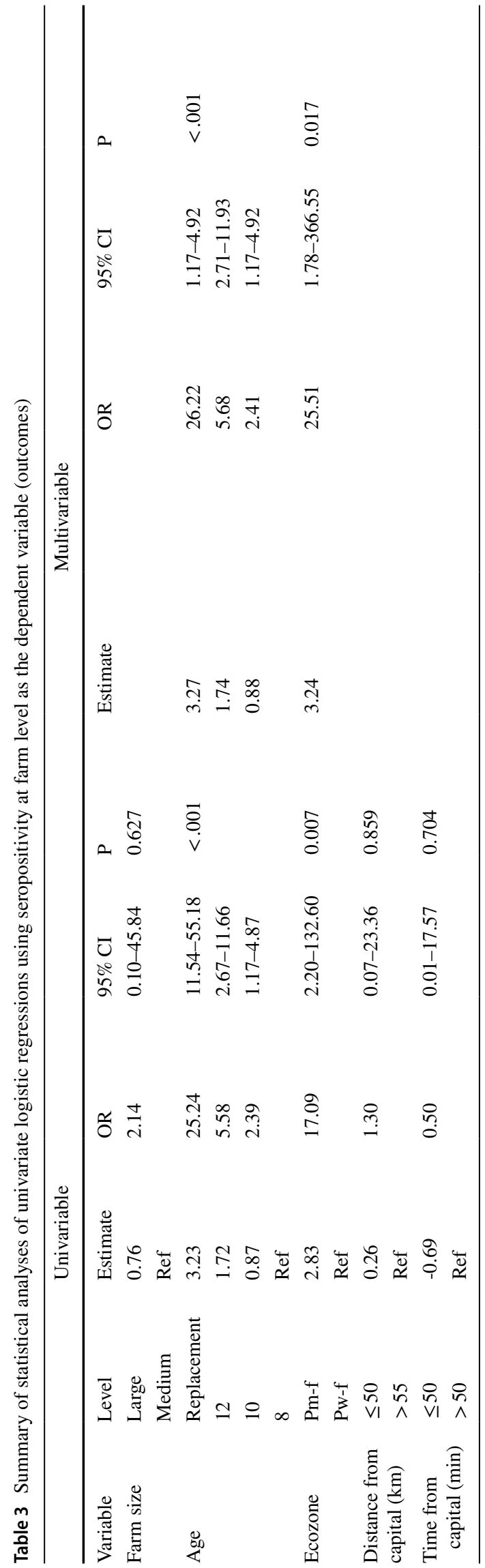

duration of viremia varies according to the PRRSV strain and the animal's age (Pileri \& Mateu, 2016).

Weaned piglets can become infected as their maternal antibodies disappear, and then they can continuously shed the virus for 3 to 8 weeks. As some reports showed, on most infected farms, most seroconversions already take place at 8 or 14 weeks of age (Lopez \& Osorio, 2004). At the end of this period, most pigs (about $80-100 \%$ ) are usually seropositive; however, the proportion of infected weaners varies among herds (Kwiecien et al., 2017) (Castro Mena, 2006). According to Evans et al. (2010), the seropositivity of young animals is indicative of the persistence of the virus in the population, while in adults, it could indicate a past exposure.

In our study, we found that ecozones are significantly related to the seroprevalence of PRRSV. Given the climatic conditions in Costa Rica, there is a significant variation in temperature during the day and night of up to 10 to $12{ }^{\circ} \mathrm{C}$. Therefore, the relative humidity on rainy days increases from 60 to $85 \%$ humidity, which predisposes respiratory problems.

Some studies have been conducted to assess the temperature, humidity, and climate conditions of PRRSV, but the results were variable across countries (Arruda et al., 2015) (Tummaruk et al., 2015). One study suggested that the PRRSV was associated with temperature and relative humidity, while temperature had a more significant effect than relative humidity. Recently, it has been suggested that climatic factors (temperature, moisture, and land use) were associated with PRRSV outbreaks in the USA (Alkhamis et al., 2018). So, the Costa Rican climate conditions may promote PRRSV dissemination with warm temperatures and some humidity.

According to the geographical distribution of PRRSV in Costa Rica, the seropositive herds are mainly in the central zone and northern part of the country due to the high density of pig farms in this region. Notably, there are at least five slaughterhouses and ten feed plants (or mills) for animals around that area, and there is an active movement of pigs, food supply, and medicines. There is also the exchange of genetic material and semen to the farms, and then they may spread the virus throughout the national territory. However, the statistical analysis in our study showed that provinces, size of the farm, location, and distance were not related to the seroprevalence.

This study estimated the seroprevalence of PRRSV in pig farms in Costa Rica and found a significant correlation between the age of pigs and ecozones, suggesting that current control measures are not effective in eliminating and maintaining PRRSV freedom. This is the first time that ecozones have been linked to PRRSV seroprevalence in Costa Rica. 
Acknowledgements The authors acknowledge the contribution of the technical staff from the Virology laboratory EMV, UNA, and the Laboratorio Nacional de Servicios Veterinarios (LANASEVE), SENASA. Also, we appreciate help from Susana Ureña to collect samples and provide data from farms and Dra. Lohendy Muñoz contributed to the geolocation in this study. We would also like to thank the pig producers involved in the research and Sietske Ruijgh for editing the paper.

Author contribution RM wrote the manuscript, conducted sampling and data analyzes.

MG conducted viral diagnostic screening.

CJ coordinated and planned the study.

MP contributed to conducting viral screening in the virology laboratory of UNA.

EJ participated in the selection of the pig farms and sample collection.

BL conducted data analysis and provided feedback on the study.

JMC offered technical advice to support laboratory assays.

LRC offered technical assistance.

AU supplied laboratory protocols for the study and critical advice.

AVN contributed to study design and provided technical and management advice.

AS contributed to study design and provided technical and management advice.

HV contributed to data analysis.

JJR contributed to study design and data analysis.

Funding RM was a recipient of a scholarship from the Ministry of Science and Technology and Telecommunications (MICITT) PND018-15-2 from PINN POSGRADOS of Costa Rica to conduct doctoral studies. This work was supported partially by the Department of Farm Animal Health, University of Utrecht. Financial contribution to this study also came from Regional Research Center for Sustainable Animal Production (CRIPAS), Universidad Nacional, Costa Rica.

Data availability The data sets analyzed during the current study are available from the corresponding author upon reasonable request.

Code availability Not Applicable

\section{Declarations}

Ethics approval and consent to participate The Ethical Committee approved this protocol of the School of Veterinary Medicine, Universidad Nacional, and consent from pork producers involved in the project was obtained for this project.

Consent to participate All authors have consented to participate.

Consent to publication All authors have approved to publish.

Conflicts of interest The authors declare no competing interests.

Open Access This article is licensed under a Creative Commons Attribution 4.0 International License, which permits use, sharing, adaptation, distribution and reproduction in any medium or format, as long as you give appropriate credit to the original author(s) and the source, provide a link to the Creative Commons licence, and indicate if changes were made. The images or other third party material in this article are included in the article's Creative Commons licence, unless indicated otherwise in a credit line to the material. If material is not included in the article's Creative Commons licence and your intended use is not permitted by statutory regulation or exceeds the permitted use, you will need to obtain permission directly from the copyright holder. To view a copy of this licence, visit http://creativecommons.org/licenses/by/4.0/.

\section{References}

Alfaro Murillo, A. L., Aymerich Uhlenhaut, N., Blanco Laurito, G., Bolaños Álvarez, L., Campos Monteros, A., \& Matarrita Ortiz, R. (2013). Guía de diseño bioclimático: Según clasificación de zonas de vida de Holdridge : [análisis climático de zonas de vida existentes en el país para la definición de estrategias pasivas por componente de la envolvente]. http://www.kerwa.ucr.ac.cr/handle/ $10669 / 16645$

Alkhamis, M. A., Arruda, A. G., Vilalta, C., Morrison, R. B., \& Perez, A. M. (2018). Surveillance of porcine reproductive and respiratory syndrome virus in the United States using risk mapping and species distribution modeling. Preventive Veterinary Medicine, 150, 135-142. https://doi.org/10.1016/j.prevetmed.2017.11.011

Arruda, A. G., Poljak, Z., Friendship, R., Carpenter, J., \& Hand, K. (2015). Descriptive analysis and spatial epidemiology of porcine reproductive and respiratory syndrome (PRRS) for swine sites participating in area regional control and elimination programs from 3 regions of Ontario. Canadian Journal of Veterinary Research, 79(4), 268-278. https://www.ncbi.nlm.nih.gov/pmc/ articles/PMC4581670/

Batista, L., Pijoan, C., Dee, S., Olin, M., Molitor, T., Joo, H. S., Xiao, Z., \& Murtaugh, M. (2004). Virological and immunological responses to porcine reproductive and respiratory syndrome virus in a large population of gilts. Canadian Journal of Veterinary Research, 68(4), 267-273. https://www.ncbi.nlm.nih.gov/pmc/ articles/PMC1111357/

Bautista, E., Morrison, R., Goyal, S., Collins, J., \& Annelli, J. (1993). Seroprevalence of PRRS virus in the United States. Journal of Swine Health and Production, 1, 4-8.

Cannon, R. M., Roe, R. T., \& Branch, A. B. of A. H. E. (1982). Livestock disease surveys: A field manual for veterinarians. Canberra : A.G.P.S. https://trove.nla.gov.au/version/45837331

Castro Mena, B. (2006). Seroprevalencia del virus del síndrome respiratorio y reproductivo porcino en las diferentes etapas de producción porcina en una granja comercial en Costa Rica. B. Castro $\mathrm{M}$.

Diaz, I. (2006). Caracterización de la respuesta inmune de lechones durante la infección y tras la vacunación con el virus del Síndrome Reproductivo y Respiratorio Porcino. In THESIS.

ESRI 2011. ArcGIS Desktop: Release 10. Redlands, CA: Environmental Systems Research Institute. (2011). Environmental Systems Research Institute.

Evans, C. M., Medley, G. F., Creasey, S. J., \& Green, L. E. (2010). A stochastic mathematical model of the within-herd transmission dynamics of porcine reproductive and respiratory syndrome virus (PRRSV): Fade-out and persistence. Preventive Veterinary Medicine, 93(4), 248-257. https://doi.org/10.1016/j.prevetmed. 2009.11.001

Holdridge, L. R. (1987). Ecología basada en zonas de vida. Agroamerica.

Holtkamp, D. J., Yeske, P. E., Polson, D. D., Melody, J. L., \& Philips, R. C. (2010). A prospective study evaluating duration of swine breeding herd PRRS virus-free status and its relationship with measured risk. Preventive Veterinary Medicine, 96(3), 186-193. https://doi.org/10.1016/j.prevetmed.2010.06.016

INEC, 2014. (2015). Censo Agropecuario 2014. Instituo Nacional de Estadistica y Censos. http://www.inec.go.cr/censos/censo-agrop ecuario-2014

Kwiecien, E., Mejía-Silva, W., Zapata, D., Quintero-Moreno, A., \& Gutierrez, C. (2017). ESTUDIO DE LA RESPUESTA 
SEROLÓGICA CONTRA EL VIRUS DEL SÍNDROME REPRODUCTIVO Y RESPIRATORIO PORCINO (PRRS) EN CERDOS BAJO CONDICIONES TROPICALES. Revista Cientifica FCV-LUZ, Vol. XXVII, 282-293.

Lopez, O. J., \& Osorio, F. A. (2004). Role of neutralizing antibodies in PRRSV protective immunity. Veterinary Immunology and Immunopathology, 102(3), 155-163. https://doi.org/10.1016/j. vetimm.2004.09.005

López-Soria, S., Maldonado, J., Riera, P., Nofrarías, M., Espinal, A., Valero, O., Blanchard, P., Jestin, A., Casal, J., Domingo, M., Artigas, C., \& Segalés, J. (2010). Selected Swine Viral Pathogens in Indoor Pigs in Spain. Seroprevalence and Farm-Level Characteristics. Transboundary and Emerging Diseases, 57(3), 171-179. https:// doi.org/10.1111/j.1865-1682.2010.01135.x

Magar, R., \& Larochelle, R. (2004). Evaluation of the presence of porcine reproductive and respiratory syndrome virus in pig meat and experimental transmission following oral exposure. Canadian Journal of Veterinary Research, 68(4), 259-266. https://www. ncbi.nlm.nih.gov/pmc/articles/PMC1111356/

Mogollón, J. D., Rincón, M. A., Peña, N. B., \& Lora, A. M. (2006). PREVALENCIA SEROLÓGICA DEL SÍNDROME REPRODUCTIVO Y RESPIRATORIO PORCINO (PRRS) EN CERDOS DE EXPLOTACIONES EXTENSIVAS DE COLOMBIA. Revista de la Facultad de Medicina Veterinaria y de Zootecnia, 53(1), 33-41. https://revistas.unal.edu.co/index.php/remevez/artic le/view/17799

Morilla, A., González-Vega, D., Vargas, F., \& Estrada, E. (2003). SEROEPIDEMIOLOGY OF PRRS IN MÉXICO.

Nieuwenhuis, N., Duinhof, T. F., \& van Nes, A. (2012). Economic analysis of outbreaks of porcine reproductive and respiratory syndrome virus in nine sow herds. The Veterinary Record, 170(9), 225. https://doi.org/10.1136/vr.100101
Pileri, E., \& Mateu, E. (2016). Review on the transmission porcine reproductive and respiratory syndrome virus between pigs and farms and impact on vaccination. Veterinary Research, 47(1). https://doi.org/10.1186/s13567-016-0391-4

SAS/STAT ® 9.3 User's Guide Introduction to Regression Procedures. (n.d.).

SIREA reconoce los esfuerzos ambientales de las instituciones. (2016, November 11). Actualidad Educativa. https://actualidadeducativa. $\mathrm{com} /$ sirea-reconoce-los-esfuerzos-ambientales-de-las-institucio nes/

Tummaruk, P., Phoophitphong, D., Olanratmanee, E., \& Thanawongnuwech, R. (2015). Detection of porcine reproductive and respiratory syndrome virus in the ovary of gilts culled due to reproductive disturbances. Comparative Clinical Pathology, 24(4), 903-910. https://doi.org/10.1007/s00580-014-2006-7

Ventura, A., Gonzalez, W., Barrette, R., Swenson, S., Bracht, A., Rowland, J., Fabian, A., Moran, K., Mohamed, F., O'Hearn, E., Jenkins-Moore, M., Toms, D., Shaw, J., Morales, P., Pyburn, D., Carrillo, C., Mayr, G., McIntosh, M., Deng, M. (2013) Virus and antibody diagnostics for swine samples of the dominican republic collected in regions near the border to Haiti. ISRN Virology, 2013, $1-7$.

Zorzetto- Fernandez, Andre. (2016). What is meant by end-point detection (quantification) of RT-PCR products? ResearchGate. https:// www.researchgate.net/post/what_is_meant_by_end-point_detec tion_quantification_of_RT-PCR_products

Publisher's note Springer Nature remains neutral with regard to jurisdictional claims in published maps and institutional affiliations. 